\title{
Physalis development according to the growing season in the semi-arid region of the Bahia state, Brazil ${ }^{1}$
}

\author{
Natália dos Santos Barroso², Josandra Souza Teles Fonseca², \\ Marilza Neves do Nascimento ${ }^{2}$, Claudinéia Regina Pelacani ${ }^{2}$
}

\section{ABSTRACT}

The Physalis ixocarpa species has an interesting performance in hot and dry regions. However, there has been a lack of information about the influence of edaphoclimatic conditions, during the growing period, on the physical and physicochemical characteristics of the fruits. This study aimed to evaluate the characteristics of 'purple' and 'green' fruits of the $P$. ixocarpa species, according to the growing season, in the semi-arid region of the Bahia state, Brazil. A randomized block design was used, in a $2 \times 2 \times 5$ factorial scheme (variety $\mathrm{x}$ growing season $\mathrm{x}$ fruit maturation stages), with three replications. The following characteristics were evaluated: color, fresh weight, length, diameter and total soluble solids contents of the fruits. The changes in the characteristics of the fruits follow the same tendency during maturation, for both evaluated varieties, with the best characteristics being observed when the calyx is green, with dry parts, completely expanded and ruptured. The growing season has a significant effect on the characteristics of the fruits, with May to August presenting the best environmental conditions for growing in the semi-arid region of the Bahia state.

KEYWORDS: Physalis ixocarpa Brot. ex Hornem; Solanaceae; fruit maturation; growing environment.

\section{INTRODUCTION}

Non-traditional fruits species, either native or exotic, which are little explored economically in Brazil, have aroused the market interest for their organoleptic, medicinal properties and acceptability by the population. Among them are mangosteen, lychee, pomegranate, mulberry, umbu, star fruit and goldenberry (physalis), in addition to other fruits (Watanabe \& Oliveira 2014).

Among the species of the Physalis genus, whose fruits are rich in compounds beneficial to the human health, and with a potential as food, is Physalis

\section{RESUMO}

Desenvolvimento de frutos de fisális

em função da época de cultivo no semiárido baiano

A espécie Physalis ixocarpa demonstra desempenho interessante em regiões quentes e secas. Contudo, há necessidade de informações acerca da influência das condições edafoclimáticas durante o cultivo nas características físicas e físico-químicas dos frutos. Objetivou-se avaliar as características de frutos das variedades 'roxa' e 'verde' de $P$. ixocarpa, em função da época de cultivo, no semiárido baiano. Utilizou-se delineamento experimental em blocos casualizados, em esquema fatorial $2 \times 2 \times$ 5 (variedade x época de cultivo x estádios de maturação do fruto), com três repetições. Avaliaram-se as seguintes características: cor, massa fresca, comprimento, diâmetro e teores de sólidos solúveis totais dos frutos. As modificações nas características dos frutos seguem a mesma tendência ao longo da maturação, nas duas variedades avaliadas, observando-se as melhores características quando o cálice está verde, com partes secas, completamente expandido e rompido. A época de cultivo tem efeito significativo nas características dos frutos, devendo este ser realizado de maio a agosto, no semiárido baiano.

PALAVRAS-CHAVE: Physalis ixocarpa Brot. ex Hornem; Solanaceae; maturação de frutos; ambiente de cultivo.

ixocarpa Brot. ex Hornem. Still little known in Brazil, the species is native to Mexico, which is the largest producer and distributor. Depending on the variety cultivated, the color of the fruits produced may be green, yellow-green or purple. They are used in the traditional Mexican cuisine and are popularly known as Mexican husk tomatoes (Peña-Lomelí et al. 2011). The fruit is also marketed in the United States, owing to the increasing demand of the Latino community in the country (Díaz-Pérez et al. 2005). In India, recent studies have been developed to introduce this fruit crop in the region (Singh et al. 2013). In Brazil, due to the fruit diverse potential (for instance, in the

1. Received: Jul. 25, 2018. Accepted: Oct. 31, 2018. Published: Dec. 07, 2018. DOI: 10.1590/1983-40632018v4854173.

2. Universidade Estadual de Feira de Santana, Departamento de Ciências Biológicas, Feira de Santana, BA, Brasil.

E-mail/ORCID: nataliasbarroso@yahoo.com.br/0000-0001-8278-5494, josandrateles@hotmail.com/0000-0002-1990-6756, marilzaagro@hotmail.com/0000-0003-3344-9106, claudineiapelacani@gmail.com/0000-0002-5230-8504. 
food and pharmaceutical industries), there has been a commercial interest, and recent studies have been carried out in the southeastern and northeastern regions of the country (Silva et al. 2016, Barroso et al. 2017).

P. ixocarpa fruits, used as vegetable, are a source of nutrients essential for the maintenance of human health (Vargas-Ponce et al. 2015). In addition, pectins with a high potential for use in the food industry (Morales-Contreras et al. 2018) can be extracted from the fruit. Besides, the extract from leaves, stem, fruits and calyx has an important pharmacological potential, due to its high antibacterial (Khan et al. 2016) and chemopreventive activity (Choi et al. 2006).

In recent years, the cultivation and commercialization of physalis, mainly Physalis peruviana, have been taking place in the centralsouth Brazil; but species of this genus are tolerant to various types of climates and soils, and have a potential to be commercially expanded to others regions of the country (Rufato et al. 2013, Muniz et al. 2015). The potential for introducing this crop to the Brazilian Northeast region, for example, can be demonstrated by studies with different species of this genus carried out by Souza et al. (2017) and with the P. ixocarpa species by Barroso et al. (2017). In those studies, the fruits presented physical and physicochemical characteristics similar to those obtained in studies carried out in places of natural occurrence and/or cultivation of the species.

With regard to the Physalis species, the season and growing environment have a significant effect on the development of the plants and, consequently, on their physical characteristics, such as weight and size, and on their chemical characteristics, such as ${ }^{\circ}$ Brix, acidity, vitamin $\mathrm{C}$ content and anthocyanins (Lima et al. 2012, Silva et al. 2016 and 2018). In addition, they influence the growth rate and development duration (Fisher et al. 2007). Therefore, studies investigating the effect of growing seasons on fruit characteristics contribute to verify the potential of this species in different regions, such as in the semiarid region. Such studies also allow identifying the appropriate crop management, as well as introducing and diversifying cultivation practices of the species, which shows a great commercial potential in the national market.

In view of the above, this study aimed to evaluate the characteristics of fruits of the 'purple' and 'green' varieties of Physalis ixocarpa, according to the growing season, in the semi-arid region of the Bahia state, Brazil.

\section{MATERIAL AND METHODS}

The experiments were conducted at the Universidade Estadual de Feira de Santana, in Feira de Santana, Bahia state, Brazil (12¹6'09'S, $38^{\circ} 56^{\prime} 34^{\prime \prime} \mathrm{W}$ and altitude of $234 \mathrm{~m}$ ), from May to August 2017 and from August to November 2017.

The region has a mean annual temperature of $24^{\circ} \mathrm{C}$, mean annual rainfall of around $848 \mathrm{~mm}$, and the climate is dry subhumid, megathermal (C2rA'a'), according to the Thornthwaite \& Mather method (UEFS 2018). The soil in the region is a Red-Yellow Podzolic (Silva 2015), with a claysandy texture and a flat relief, showing the following chemical characteristics: organic matter $=24.0 \mathrm{~g} \mathrm{~kg}^{-1}$; $\mathrm{Ca}=2.8 \mathrm{cmol}_{\mathrm{c}} \mathrm{dm}^{-3} ; \mathrm{K}=0.15 \mathrm{cmol}_{\mathrm{c}} \mathrm{dm}^{-3} ; \mathrm{Mg}=$ $1.05 \mathrm{cmol}_{\mathrm{c}} \mathrm{dm}^{-3} ; \mathrm{Na}=0.05 \mathrm{cmol}_{\mathrm{c}} \mathrm{dm}^{-3} ; \mathrm{H}+\mathrm{Al}=$ $1.98 \mathrm{cmol}_{\mathrm{c}}^{\mathrm{c}} \mathrm{dm}^{-3}$; sum of bases $=4.04 \mathrm{cmol} \mathrm{dm}_{\mathrm{c}}^{-3}$; cation exchange capacity $=124.7 \mathrm{cmol}_{\mathrm{c}} \mathrm{dm}^{-3}$; base saturation $=67 \% ; \mathrm{P}=15 \mathrm{mg} \mathrm{dm}^{-3}$; and $\mathrm{pH}=6.1$.

A complete randomized block design was used, with three replications, each plot with 20 plants, in a $2 \times 2 \times 5$ factorial scheme, in which two varieties of Physalis ixocarpa, the 'purple' and the 'green' ones, were evaluated during two growing seasons: season 1 (May to August 2017), when there is a higher total rainfall and milder temperatures; and season 2 (August to November 2017), in which rainfall decreases and temperature increases (Figure 1), and five stages of fruit maturation.

For the production of the 'purple' and 'green' seedlings of $P$. ixocarpa, seeds were sown in $300 \mathrm{~mL}$ plastic cups filled with the commercial substrate Vivatto Slim Plus ${ }^{\circledR}$. After the seedling emergence, thinning was carried out, leaving only one seedling per cup. These seedlings were kept under shade-cloth cover and daily irrigation. From the emergence of the first eophyll pairs, after 20 days, 120 seedlings were transplanted to open field conditions. The seedlings were arranged in two rows per block, with spacing of $0.8 \mathrm{~m}$ between plants and $2.0 \mathrm{~m}$ between rows. A chemical fertilizer with NPK was used, as recommended by Thomé \& Osaki (2010).

During the growing period, the branches were staked in an " $X$ " format, following the recommendation by Muniz et al. (2011). The plants 


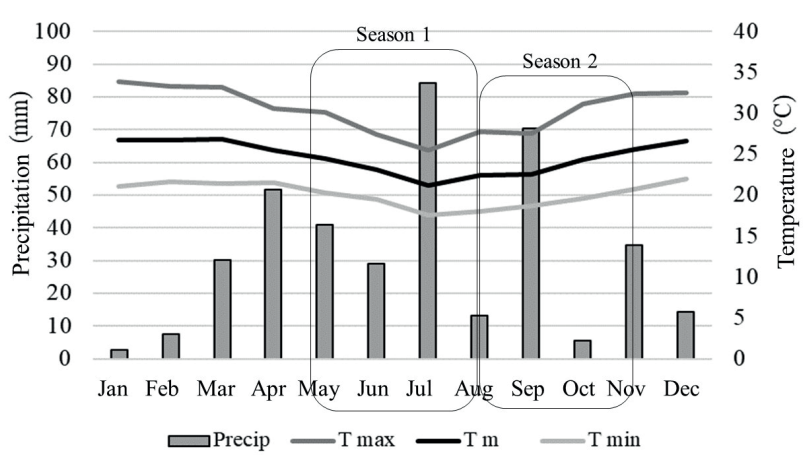

Figure 1. Variations of monthly minimum (Tmin), mean (Tm) and maximum (Tmax) air temperature and rainfall levels (precipitation), during the experimental period, in Feira de Santana, Bahia state, Brazil. Source: Brasil (2018).

were marked with ribbons one month after the transplant, staking the new branches as needed throughout the plant developmental stage. The irrigation system consisted of drippers spaced at every $0.8 \mathrm{~cm}$. For pest control, a commercial neem oil ( $1 \%$ emulsifiable oil solution) diluted in water in the proportion of $5 \mathrm{~mL} \mathrm{~L}^{-1}$ was used whenever necessary.

At 40 days after transplanting, at different positions and orientations in the plant, fruits in different stages were collected, and the maturation stages were determined according to the description of the characteristics and images of calyx and fruit displayed in the publication by Barroso et al. (2017). By means of visual selection, the fruits were grouped into five stages: E1 - green calyx not completely expanded, and fruit not filling the calyx; E2 - green and fully expanded calyx, and fruit not filling the calyx; E3 - green and fully expanded calyx, and fruit completely filling the calyx; E4 - green calyx, with dry parts, completely expanded and ruptured, and fruit completely filling the calyx; E5 - dry, fully expanded and ruptured calyx, and fruit completely filling the calyx.

Using the Royal Horticultural Society color chart (RHS 2001), calyx and fruit colors were determined. In addition to color, the analysis also determined the fresh weight $(\mathrm{g})$ using a Shimadzu AY220 analytical scale $(0.001 \mathrm{~g})$, fruit diameter (measured in equatorial plane) and fruit length (mm) (apex to base), using a $0.01 \mathrm{~mm}$ Cosa digital caliper. The total soluble solids content was measured indirectly by placing a drop of fruit juice on the prism of an Atago manual refractometer, with temperature correction at $20^{\circ} \mathrm{C}$ and expressed in ${ }^{\circ}$ Brix.
The analyses followed a randomized design, consisting of three replications, and each plot was represented by 15 fruits (collected from 20 plants per plot), totaling 45 fruits per stage. The results were submitted to analysis of variance by the $\mathrm{F}$ test and, when the effect of the factors and of the interaction between them were significant, a test of comparison of averages (Tukey) was performed at a $5 \%$ significance level. Data analysis was performed using the Sisvar software (Ferreira 2011).

\section{RESULTS AND DISCUSSION}

Changes in the characteristics of calyces and fruits followed the same tendency, regardless of the growing season, for the 'purple' and 'green' varieties of Physalis ixocarpa, showing changes only in the final stages (Figure 2).

Regarding fruit color, no marked changes were observed for the 'green' variety. Observations showed that the fruits maintain their dark green color (144A-RHS) during almost all their development period, varying in tonality, thus becoming light green (145A-RHS) only when changes in the calyx color occur [light yellowish brown (158A-RHS)].

The 'purple' variety, like most physalis species, showed changes in color in the calyx and fruit when fully developed. The dark green color (144A-RHS) of the fruits was maintained until near the stage of maximum maturation (stage 4), when the calyx is ruptured and part of the fruit surface begins to become purple (N89A-RHS), what is then accentuated in the last stage evaluated. The purple color of the fruits of this variety is associated with the presence of anthocyanin (Gonzáles-Mendonza et al. 2011). This pigment is detected in higher contents in the final stages of fruit maturation (Borghesi et al. 2016), because, besides being an important protective mechanism against solar radiation, an antioxidant and a defense mechanism, it plays a role in attracting seed dispersers and delays senescence (Liu et al. 2018).

Unlike the species $P$. angulata and $P$. peruviana, among other species of the genus, the changes in the color of calyx and fruit for the evaluated varieties are not gradual throughout the developmental stages (Rodrigues et al. 2012, Carvalho et al. 2014). Changes occurred only in the final maturation stages. This observation can be explained by the intrinsic genetic aspect of the species, since the two varieties 
under analysis showed the same tendency, and the color-change pattern was the same in the two evaluated periods.

The statistical analyses showed a triple interaction (season $\mathrm{x}$ variety $\mathrm{x}$ maturation stages of the fruit) only for the variable fruit fresh weight. This demonstrated that the fruit increased weight during its development depends on the environmental conditions and the $P$. ixocarpa variety being cultivated.

The increase in the fruit fresh weight during maturation showed a significant difference and followed the same tendency for the two varieties and growing seasons evaluated (Table 1). The fruits showed a similar weight for both varieties at the initial stages of development in the two growing seasons (E1 and E2); but, from the stage 3, the fruits of the 'green' variety were heavier than those of the 'purple' variety, in the evaluated periods.

The highest average for fresh weight $(36.4 \mathrm{~g})$ was verified for the 'green' P. ixocarpa in fruits with dry and completely ruptured calyx obtained from May to August 2017 (season 1). This value is similar to that found for the 'green' variety by Souza et al. (2017) and Barroso et al. (2017), for plants grown at the same place that the present study was carried out. However, when compared to the average of $30.5 \mathrm{~g}$ verified by Rodríguez-Burgos et al. (2011) - the highest value among the varieties studied by these authors - and the average of $27.96 \mathrm{~g}$ observed
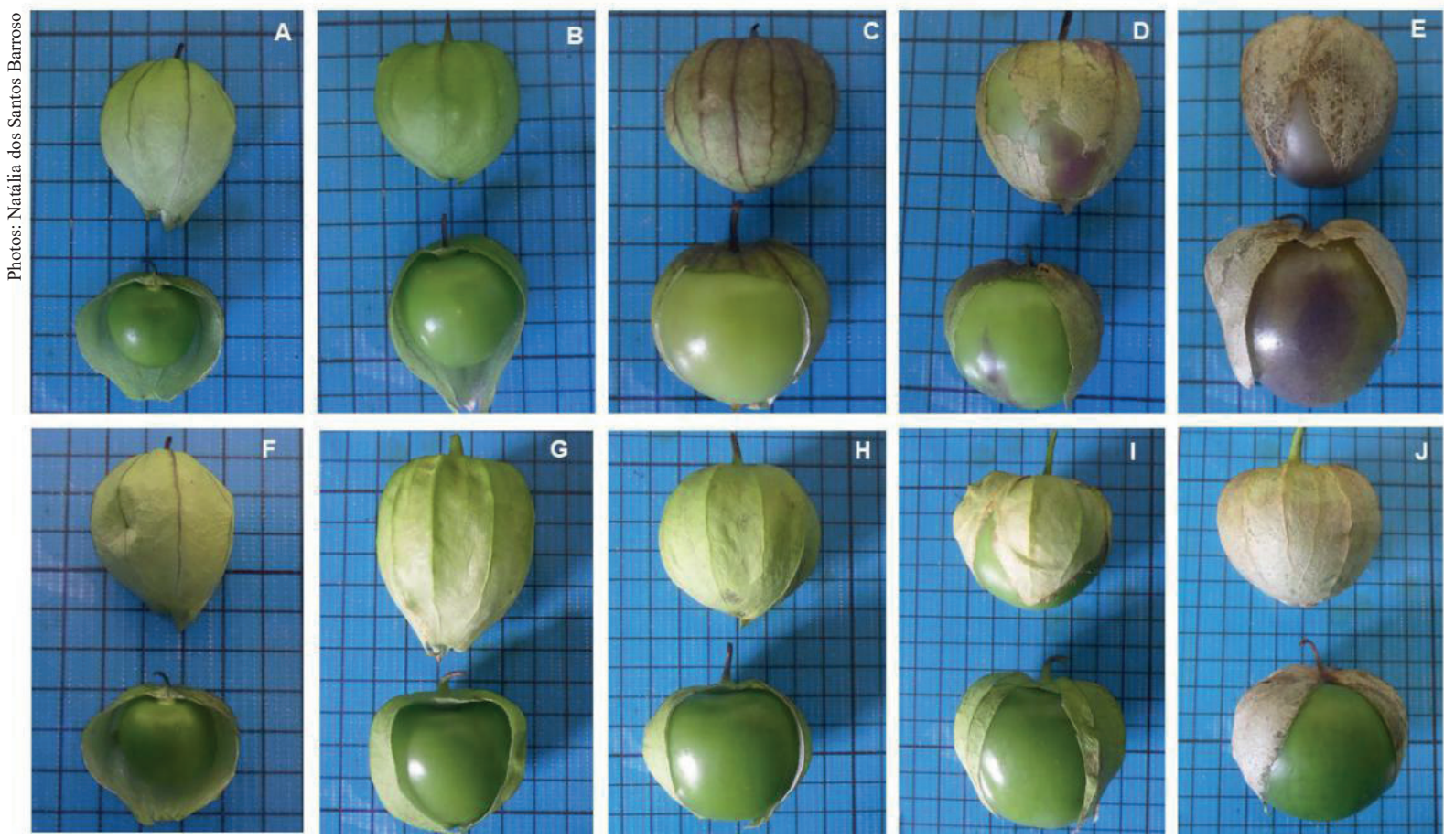

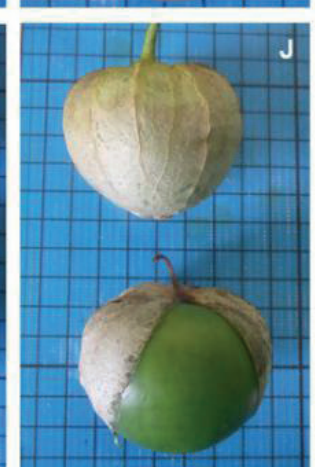

Figure 2. Visual aspects of Physalis ixocarpa fruits at different maturation stages of the 'purple' [S1 (A); S2 (B); S3 (C); S4 (D); S5 (E)] and 'green' [S1 (F); S2 (G); S3 (H); S4 (I); S5 (J)] varieties. Each square equals $1 \mathrm{~mm}^{2}$.

Table 1. Fruit fresh weight at five maturation stages of the 'purple' and 'green' varieties of Physalis ixocarpa produced in two seasons: from May to August 2017 (season 1) and from August to November 2017 (season 2).

\begin{tabular}{ccccccccccc}
\hline \multirow{2}{*}{ Season } & \multicolumn{2}{c}{ Stage 1 } & \multicolumn{2}{c}{ Stage 2 } & \multicolumn{2}{c}{ Stage 3 } & \multicolumn{2}{c}{ Stage 4 } & \multicolumn{2}{c}{ Stage 5 } \\
\cline { 2 - 11 } & Purple & Green & Purple & Green & Purple & Green & Purple & Green & Purple & Green \\
\hline 1 & $3.8 \mathrm{aA} *$ & $6.3 \mathrm{aA}$ & $7.4 \mathrm{aA}$ & $11.7 \mathrm{aA}$ & $11.4 \mathrm{aB}$ & $18.7 \mathrm{aA}$ & $23.1 \mathrm{aB}$ & $34.6 \mathrm{aA}$ & $28.4 \mathrm{aB}$ & $36.4 \mathrm{aA}$ \\
2 & $3.3 \mathrm{aA}$ & $5.6 \mathrm{aA}$ & $8.2 \mathrm{aA}$ & $11.7 \mathrm{aA}$ & $12.9 \mathrm{aB}$ & $18.0 \mathrm{aA}$ & $12.6 \mathrm{bB}$ & $22.4 \mathrm{bA}$ & $11.2 \mathrm{bB}$ & $23.1 \mathrm{bA}$ \\
\hline $\mathrm{CV}(\%)$ & & & & \multicolumn{4}{c}{18.72} & & &
\end{tabular}

* Means followed by the same letter, lowercase in the column (growing season) and uppercase in the row (maturation stage), do not differ by the Tukey test at a $5 \%$ significance level. 
by Ramos-Lopez et al. (2017), both studies conducted in Mexico, the result obtained in the present study was above those values. This indicates that the semiarid climate conditions favor the production of fruits with a greater weight and, consequently, with more interesting attributes for the customer market.

The higher fresh weight of fruits produced from May to August 2017 may be related to the greater availability of water at that time. At the place where the study was developed, this is the period when higher rainfall levels and milder temperatures occur (Figure 1). These conditions favor the development of fruits with a greater weight and size (Ramos-Lopez et al. 2017). Growing seasons with higher temperatures, lower rainfall levels and greater radiance, as in the months of August to November, can generate an environment in which the plant needs to redirect its metabolism to tolerate such conditions, thus reducing the plant investment in fruit development, what accelerates the fruit maturation and results in less developed fruits (Hasanuzzaman et al. 2013).

Regarding the variables length, diameter and total soluble solids contents, the effect of the interaction season $\mathrm{x}$ variety $\mathrm{x}$ maturation stages was not significant. However, when the growing season and maturation stage were tested separately, there was a significant difference for the 'purple' and 'green' varieties (Table 2).

The total soluble solids content of the fruits was not significantly influenced by the growing season for both varieties at all maturation stages evaluated (Table 2). However, a significant difference was observed between the stages, increasing the total soluble solids content with fruit maturation. This may be related to the metabolic processes that occur with fruit maturation, such as biosynthesis or degradation of polysaccharides or loss of fruit water, resulting in an increase in the amount of sugar in the fruit (Chitarra \& Chitarra 2005).

The highest values for the total soluble solids content of the 'purple' and 'green' P. ixocarpa varieties (respectively $5.8^{\circ} \mathrm{Brix}$ and $6.2^{\circ} \mathrm{Brix}$ ) were verified in mature fruits collected in the first growing season. These values are similar to those found in recent studies carried out with that species in the same region as in the present study, as well as in crops grown in Mexico (Benito-Bautista et al. 2016, Barroso et al. 2017, Ramos-Lopez et al. 2017, Souza et al. 2017). Thus, the value found in the study is within the expected range for mature fruits of this species used as vegetables.

A significant growth in length and diameter occurred up to the fourth stage evaluated (E4), reaching, respectively, $31 \mathrm{~mm}$ and $34.6 \mathrm{~mm}$ for the 'purple' variety and $34.4 \mathrm{~mm}$ and $40.9 \mathrm{~mm}$ for the 'green' variety (Table 2). These results demonstrate the potential of the semi-arid region for the production of fruits of this species, because they are similar to those obtained for mature fruits of $P$. ixocarpa in studies carried out in Mexico by Rodríguez-Burgos

Table 2. Length (L), diameter (D) and total soluble solids content (TSSC) at five maturation stages of the 'purple' and 'green' varieties of Physalis ixocarpa fruits produced in two seasons: from May to August 2017 (season 1) and from August to November 2017 (season 2).

\begin{tabular}{|c|c|c|c|c|c|c|}
\hline \multirow{2}{*}{ Variable } & \multirow{2}{*}{ Season } & \multicolumn{5}{|c|}{ Maturation stage (S) } \\
\hline & & $\mathrm{S} 1$ & $\mathrm{~S} 2$ & S3 & $\mathrm{S} 4$ & S5 \\
\hline \multicolumn{7}{|c|}{ 'Purple' P. ixocarpa } \\
\hline \multirow{2}{*}{ TSSC ( $\left({ }^{\circ}\right.$ Brix $)$} & 1 & $4.2 \mathrm{aB}^{*}$ & $4.5 \mathrm{aB}$ & $4.6 \mathrm{aB}$ & $5.1 \mathrm{aAB}$ & $5.8 \mathrm{aA}$ \\
\hline & 2 & $3.9 \mathrm{aB}$ & $4.2 \mathrm{aB}$ & $4.7 \mathrm{aAB}$ & $4.8 \mathrm{aAB}$ & $5.4 \mathrm{aA}$ \\
\hline \multirow{2}{*}{$\mathrm{L}(\mathrm{mm})$} & 1 & $18.6 \mathrm{aB}$ & $22.4 \mathrm{aAB}$ & $28.8 \mathrm{aAB}$ & $31.0 \mathrm{aA}$ & $30.9 \mathrm{aA}$ \\
\hline & 2 & $17.2 \mathrm{aC}$ & $22.6 \mathrm{aB}$ & $26.1 \mathrm{aA}$ & $25.6 \mathrm{bA}$ & $24.5 \mathrm{bA}$ \\
\hline \multirow{2}{*}{$\mathrm{D}(\mathrm{mm})$} & 1 & $21.2 \mathrm{aB}$ & $26.2 \mathrm{aB}$ & $34.4 \mathrm{aAB}$ & $34.6 \mathrm{aA}$ & $36.0 \mathrm{aA}$ \\
\hline & 2 & $19.3 \mathrm{aB}$ & $26.4 \mathrm{aB}$ & $30.4 \mathrm{aAB}$ & $29.4 \mathrm{bA}$ & $28.1 \mathrm{bA}$ \\
\hline \multicolumn{7}{|c|}{ 'Green' P. ixocarpa } \\
\hline \multirow{2}{*}{$\operatorname{TSSC}\left({ }^{\circ}\right.$ Brix $)$} & 1 & $4.5 \mathrm{aB}$ & $4.6 \mathrm{aB}$ & $5.3 \mathrm{aB}$ & $6.2 \mathrm{aA}$ & $6.2 \mathrm{aA}$ \\
\hline & 2 & $4.0 \mathrm{aB}$ & $4.8 \mathrm{aB}$ & $4.7 \mathrm{aB}$ & $5.8 \mathrm{aA}$ & $6.0 \mathrm{aA}$ \\
\hline \multirow{2}{*}{$\mathrm{L}(\mathrm{mm})$} & 1 & $19.7 \mathrm{aB}$ & $24.3 \mathrm{aAB}$ & $28.1 \mathrm{aAB}$ & $34.4 \mathrm{aA}$ & $33.9 \mathrm{aA}$ \\
\hline & 2 & $18.7 \mathrm{aC}$ & $23.6 \mathrm{aB}$ & $27.2 \mathrm{aAB}$ & $28.7 \mathrm{bA}$ & $27.4 \mathrm{bA}$ \\
\hline \multirow{2}{*}{$\mathrm{D}(\mathrm{mm})$} & 1 & $23.8 \mathrm{aC}$ & $29.4 \mathrm{aBC}$ & $33.7 \mathrm{aAB}$ & $40.9 \mathrm{aA}$ & $41.4 \mathrm{aA}$ \\
\hline & 2 & $23.4 \mathrm{aC}$ & $29.8 \mathrm{aBC}$ & $33.8 \mathrm{aAB}$ & $36.7 \mathrm{bA}$ & $34.9 \mathrm{bA}$ \\
\hline
\end{tabular}


et al. (2011) and Ramos-Lopez et al. (2017), and were higher than the values observed by Silva et al. (2018) for crops in southeastern Brazil.

Similarly to what occurred in the maturation stages, the growing seasons influenced fruit length and diameter only at the final stages evaluated for both varieties. The fruits produced from May to August (season 1) had averages higher than those for fruits produced from August to November (season 2). This can be explained by the results observed in recent studies with physalis. In this period, the growing conditions influenced the development and growth of physalis plants and, consequently, the quality of the fruits produced (Lima et al. 2012).

\section{CONCLUSIONS}

1. In the semi-arid region of the Bahia state, Brazil, Physalis ixocarpa should be grown under environmental conditions from May to August;

2. Changes in fruit characteristics along the stages follow the same tendency, regardless of the growing season, for both the 'green' and 'purple' varieties of $P$. ixocarpa;

3. The best fruit characteristics are observed when the calyx is green, with dry parts, completely expanded and ruptured.

\section{ACKNOWLEDGMENTS}

To the Universidade Estadual de Feira de Santana (UEFS) and Coordenação de Aperfeiçoamento de Pessoal de Nível Superior (Capes), for the scholarship granted.

\section{REFERENCES}

BARROSO, N. S. et al. Maturation stages of fruits and physiological seed quality of Physalis ixocarpa Brot. Ex Hormen. Revista Brasileira de Fruticultura, v. 39, n. 3, p. 1-9, 2017.

BENITO-BAUTISTA, P. et al. Color y estado de madurez del fruto de tomate de cáscara. Agronomía Mesoamericana, v. 27, n. 1, p. 115-130, 2016.

BORGHESI, E. et al. Comparative physiology during ripening in tomato rich-anthocyanins fruits. Plant Growth Regulation, v. 80, n. 2, p. 207-214, 2016.

BRASIL. Instituto Nacional de Meteorologia. Estações automáticas: gráficos. 2018. Available at: <http://www. inmet.gov.br>. Access on: 28 Feb. 2018.
CARVALHO, T. C. et al. Germinação de sementes de Physalis angulata L.: estádio de maturação do cálice e forma de armazenamento. Pesquisa Agropecuária Tropical, v. 44, n. 4, p. 357-362, 2014.

CHITARRA, M. I. F.; CHITARRA, A. B. Fatores précolheita e colheita. In: CHITARRA, M. I. F.; CHITARRA, A. B. Pós-colheita de frutas e hortaliças: fisiologia e manuseio. Lavras: Ed. UFLa, 2005. p. 203-288.

CHOI, J. K. et al. Ixocarpalactone A isolated from the Mexican tomatillo shows potent antiproliferative and apoptotic activity in colon cancer cells. The FEBS journal, v. 273, n. 24, p. 5714-5723, 2006.

DÍAZ-PÉREZ, J. C. et al. Root zone temperature, plant growth and fruit yield of tomatillo as affected by plastic film mulch. HortScience, v. 40, n. 5, p. 1312-1319, 2005.

FERREIRA, D. F. Sisvar: a computer statistical analysis system. Ciência e Agrotecnologia, v. 35, n. 6, p. 10391042, 2011.

FISCHER, G.; EBERT, G.; LUDDERS, P. Production, seeds and carbohydrate contents of cape gooseberry (Physalis peruviana L.) fruits grown at two contrasting Colombian altitudes. Journal of Applied Botany and Food Quality, v. 81, n. 1, p. 29-35, 2007.

GONZÁLEZ-MENDOZA, D. et al. Phenolic compounds and physiochemical analysis of Physalis ixocarpa genotypes. Scientific Research and Essays, v. 6, n. 17, p. 3808-3814, 2011.

HASANUZZAMAN, M. et al. Physiological, biochemical and molecular mechanisms of heat stress tolerance in plants. International Journal of Molecular Sciences, v. 14, n. 5, p. 9643-9684, 2013.

KHAN, W. et al. Antimicrobial potentials of different solvent extracted samples from Physalis ixocarpa. Pakistan Journal of Pharmaceutical Sciences, v. 29, n. 2, p. 467-475, 2016.

LIMA, C. S. M. et al. Avaliação física, química e fitoquímica de frutos de Physalis, ao longo do período de colheita. Revista Brasileira de Fruticultura, v. 34, n. 4, p. 1004-1012, 2012.

LIU, Y. et al. Anthocyanin biosynthesis and degradation mechanisms in Solanaceous vegetables: a review. Frontiers in Chemistry, v. 6, n. 52, p. 1-17, 2018.

MORALES-CONTRERAS, B. E. et al. Pectin from husk tomato (Physalis ixocarpa Brot.): rheological behavior at different extraction conditions. Carbohydrate Polymers, v. 179, n. 1, p. 282-289, 2018.

MUNIZ, J. et al. Physalis: panorama produtivo e econômico no Brasil. Horticultura Brasileira, v. 33, n. 2, não paginado, 2015. 
MUNIZ, J. et al. Sistemas de condução para o cultivo de Physalis no planalto catarinense. Revista Brasileira de Fruticultura, v. 33, n. 3, p. 830-838, 2011.

PEÑA-LOMELÍ, A. et al. Manual grafico para la descripción varietal de tomate de cáscara (Physalis ixocarpa Brot. ex Horm.). Chapingo: SNICS-SAGARPA, 2011.

RAMOS-LÓPEZ, B. I. et al. Consumo de agua y rendimiento de tomate de cáscara bajo diferentes cubiertas de invernaderos. Horticultura Brasileira, v. 35, n. 2, p. 265-270, 2017.

RODRIGUES, F. A. et al. Caracterização do ponto de colheita de Physalis peruviana na região de lavras, MG. Bioscience Journal, v. 28, n. 6, p. 862-867, 2012.

RODRÍGUEZ-BURGOS, A. et al. Desarrollo de fruto y semilla de cinco variedades de tomate de cáscara en Sinaloa. Revista Mexicana de Ciencias Agrícolas, v. 2, n. 5, p. 673-687, 2011.

RUFATO, A. R. et al. A cultura da physalis. In: KRETZSCHMAR, A. A.; RUFATO, L.; PELIZZA, T. R. (Orgs.). Pequenas frutas. Florianópolis: Ed. Udesc, 2013. p. 143-194.

SILVA, A. C. Caracterização agronômica, molecular e fitoquímica de Eplingiella Harley \& J. F. B. PASTORE. 2015. 125 f. Tese (Doutorado em Recursos Genéticos Vegetais) - Universidade Estadual de Feira de Santana, Feira de Santana, 2015.

SILVA, D. F. D. et al. Productive and qualitative parameters of Physalis species cultivated under colored shade nets. Revista Brasileira de Fruticultura, v. 40, n. 2, e-528, 2018.

SILVA, D. F. et al. Light spectrum on the quality of fruits of Physalis species in subtropical area. Bragantia, v. 75, n. 3, p. 371-376, 2016.

SINGH, D. B. et al. Introduction, characterisation and evaluation of husk tomato (Physalis ixocarpa Brot.) genotypes under temperate climate. Indian Journal of Plant Genetic Resources, v. 26, n. 3, p. 226-230, 2013.

SOUZA, C. L. M. et al. Biometric characteristics of fruits and physiological characterization of seeds of Physalis species (Solanaceae). Revista Brasileira de Ciências Agrárias, v. 12, n. 3, p. 277-282, 2017.

THE ROYAL HORTICULTURAL SOCIETY (RHS). Colour chart. London: RHS, 2001.

THOMÉ, M.; OSAKI, F. Adubação de nitrogênio, fósforo e potássio no rendimento de Physalis spp. Revista Acadêmica: Ciência Animal, v. 8, n. 1, p. 11-18, 2010.

UNIVERSIDADE ESTADUAL DE FEIRA DE SANTANA (UEFS). Estação Climatológica. Caracterização climática de Feira de Santana. 2018. Available at: <http://www.uefs.br/estacaoclimatologica/ climafeira.html>. Access on: 19 May 2018.

VARGAS-PONCE, O. et al. Potencial alimenticio de los tomates de cáscara (Physalis spp.) de México. Agroproductividad, v. 8, n. 1, p. 17-23, 2015.

WATANABE, H. S.; OLIVEIRA, S. L. Comercialização de frutas exóticas. Revista Brasileira de Fruticultura, v. 36, n. 1, p. 23-38, 2014. 